\title{
Pilomotor seizure
}

\section{When paroxysmal gooseflesh heralds brain tumor}

田

Figure Brain MRI
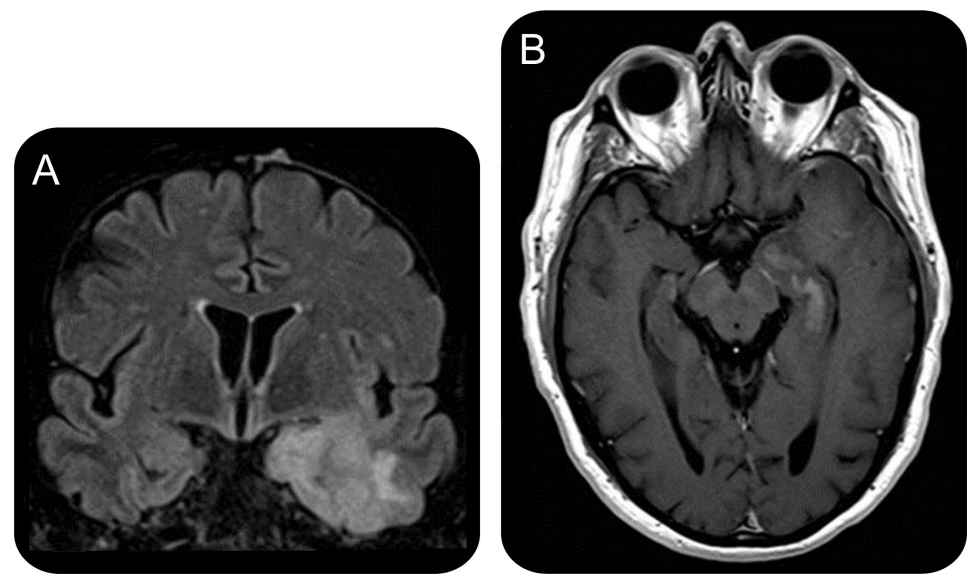

Brain MRI shows a tumoral mass located in the mesial aspect of the left temporal lobe surrounded by edema ( $A$, coronal slice, fluid-attenuated inversion recovery image) and demonstrates hippocampal enhancement after gadolinium infusion ( $B$, axial slice, T1-weighted image).

A 68-year-old man complained of acute and recurrent episodes of diffuse gooseflesh variably accompanied by nonfluent aphasia, emotional distress, and focal myoclonic jerks (video 1 on the Neurology ${ }^{\circledR}$ Web site at www.neurology.org), lasting about 2 minutes and occurring up to every 15 minutes. Contemporaneous EEG recording showed epileptic discharges over left temporal derivations (video 2). MRI showed a left temporal mass extending from the temporal pole to the pulvinar and involving amygdala and hippocampus (figure). Seizures were managed with valproate and levetiracetam. Partial lobectomy was performed demonstrating a grade III anaplastic astrocytoma. Pilomotor seizure ${ }^{1,2}$ is a rare subtype of autonomic epilepsy related to temporal lesion of which it may be the presenting symptom, usually associated with other manifestations of temporal lobe epilepsy.

\section{Fisch, $M D,{ }^{*}$ P. Mégevand, MD, *A. Badoud, PhD, M. Seeck, MD, P.R. Burkhard, MD, Geneva, Switzerland}

*These authors contributed equally to this work.

Author contributions: Dr. Fisch: drafting and editing of the manuscript, acquisition, analysis, and interpretation of data. Dr. Mégevand: drafting and editing of the manuscript, acquisition, analysis, and interpretation of data. S. Badoud: drafting the manuscript, acquisition, analysis, and interpretation of data. Prof. Seeck: revision of the manuscript, acquisition, analysis, and interpretation of data. Prof. Burkhard: revision of the manuscript, acquisition, analysis and interpretation of data, study supervision and coordination.

Supplemental data at www.neurology.org

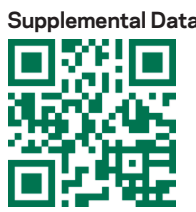

Disclosure: Dr. Fisch, Dr. Mégevand, and S. Badoud report no disclosures. Prof. Seeck serves on the editorial boards of Epilepsy Research, Epileptic Disorders, and Swiss Archives of Neurology and Psychiatry; and receives research support from the Swiss National Science Foundation. Prof. Burkhard has received funding for travel and speaker honoraria from Boehringer Ingelheim, Lundbeck, Inc., UCB, Novartis, and Eli Lilly\& Company; serves as an Associate Editor for Journal of Proteomics and on the editorial board of Revue Médicale Suisse; and receives research support from the Hamburger Foundation and the Burgauer family.

Correspondence \& reprint requests to Dr. Burkhard: Pierre.Burkhard@hcuge.ch

1. Loddenkemper T, Kellinghaus C, Gandjour J, et al. Localising and lateralising value of ictal piloerection. J Neurol Neurosurg Psychiatry 2004;75:879-883.

2. Roze E, Oubary P, Chédru F. Status-like recurrent pilomotor seizures: case report and review of the literature. J Neurol Neurosurg Psychiatry 2000;68:647-649. 


\section{Neurology}

Pilomotor seizure: When paroxysmal gooseflesh heralds brain tumor L. Fisch, P. Mégevand, A. Badoud, et al. Neurology 2012;78;1189

DOI 10.1212/WNL.0b013e31824f80f5

This information is current as of April 9, 2012

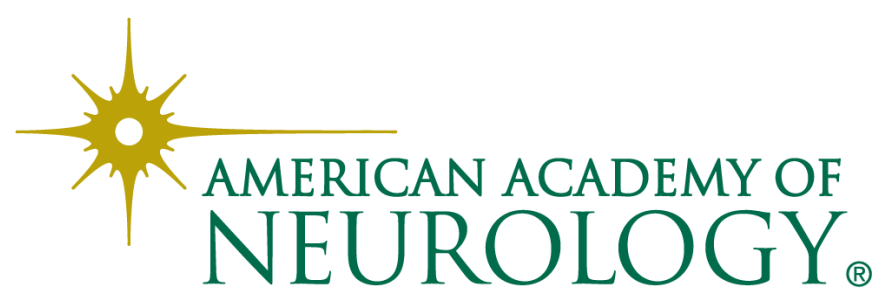




\section{Updated Information \& Services}

\section{Supplementary Material}

\section{References}

\section{Subspecialty Collections}

\section{Errata}

Permissions \& Licensing

\section{Reprints}

including high resolution figures, can be found at: http://n.neurology.org/content/78/15/1189.full

Supplementary material can be found at: http://n.neurology.org/content/suppl/2012/04/08/78.15.1189.DC1

This article cites 2 articles, 2 of which you can access for free at: http://n.neurology.org/content/78/15/1189.full\#ref-list-1

This article, along with others on similar topics, appears in the following collection(s):

All Clinical Neurology

http://n.neurology.org/cgi/collection/all_clinical_neurology EEG; see Epilepsy/Seizures

http://n.neurology.org/cgi/collection/eeg_see_epilepsy-seizures

MRI

http://n.neurology.org/cgi/collection/mri

Partial seizures

http://n.neurology.org/cgi/collection/partial_seizures

Primary brain tumor

http://n.neurology.org/cgi/collection/primary_brain_tumor

An erratum has been published regarding this article. Please see next page or:

/content/79/2/199.full.pdf

Information about reproducing this article in parts (figures,tables) or in its entirety can be found online at:

http://www.neurology.org/about/about_the_journal\#permissions

Information about ordering reprints can be found online:

http://n.neurology.org/subscribers/advertise

Neurology ${ }^{\circledR}$ is the official journal of the American Academy of Neurology. Published continuously since 1951, it is now a weekly with 48 issues per year. Copyright Copyright (? 2012 by AAN Enterprises, Inc.. All rights reserved. Print ISSN: 0028-3878. Online ISSN: 1526-632X.

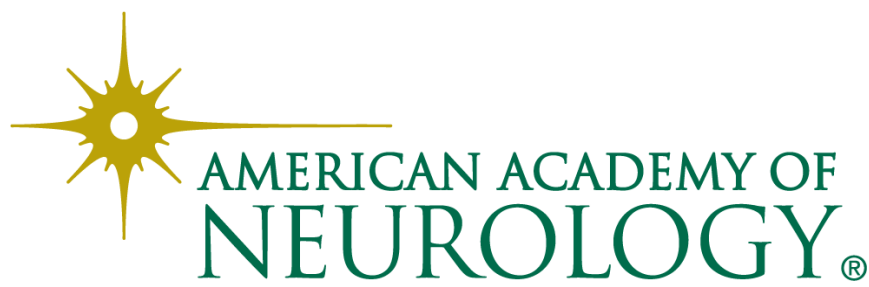


Editors' Note: WriteClick is restricted to comments about studies published in Neurology ${ }^{\circledR}$ within the past 8 weeks. The submission below represents an exception because it addresses a genetic sequencing error published in Neurology in 2003. In addition, these WriteClick submissions will be available as open access to all readers in an effort to further publicize the Correction.

chorea-acanthocytosis (ChAc) that constituted a significant challenge to the generally accepted recessive inheritance of this disorder. ${ }^{2}$ This, and other articles concerning the same family, ${ }^{3-5}$ led to a debate in the research community. ${ }^{6}$

Tomiyasu et al. ${ }^{7}$ noted that the proband reported by Saiki et al. is indeed compound heterozygous for mutations in the VPS13A (CHAC) gene and, therefore, a typical recessive $\mathrm{ChAc}$ case. Subsequent to the publication of this report, we found the Correction only via PubMed but missed the original Correction in Neurology. ${ }^{1}$

In their Correction, ${ }^{1}$ Saiki et al. mention with regret that "an error in sequencing occurred and the inheritance pattern should have been reported as autosomal recessive," with no reference to the recent publication of the full details of the mutations in this family. ${ }^{7}$ This Correction effectively changes the impact of the original article and, even more so, its title message. We feel that it would be appropriate to retract the 2003 paper in order to reduce further confusion in the literature.

Alternatively, a more compelling communication from the original authors about the significance of the new data could be offered in a manner readily accessible to the scientific community.

Author Response: Shinji Saiki, Ishikawa, Japan: We regret the error published in our 2003 article. $^{1}$ Concerning a pedigree with chorea-acanthocytosis in our previous reports, ${ }^{1,3-5,8}$ we would like to correct genetics materials associated with our pedigree already revised by Tomiyasu et al. 7 In addition to a heterozygous splice site mutation $(8035 \mathrm{G}>\mathrm{A}$, transcript variant A [GenBank NM_033305.2]), which we had reported as $8295 \mathrm{G}>\mathrm{A}$ (using a different accession number) in the VPS13A genes of the patients (III-2 and III-3), we identified a novel nonsense mutation $(1305 \mathrm{G}>\mathrm{A}, \mathrm{W} 435 \mathrm{X})$ in the genes of the unaffected mother (II-4) and patients III-2 and III-3.7 According to them, the inheritance pattern of the pedigree is actually autosomal recessive (pseudodominant).

We apologize for the mistake and deeply regret any inconvenience this publication has caused for others.

Copyright (C) 2012 by AAN Enterprises, Inc.

1. Saiki S, Sakai K, Kitagawa Y, Saiki M, Kataoka S, Hirose G. Mutation in the $C H A C$ gene in a family of autosomal dominant chorea-acanthocytosis [published Correction appears in 2011;77:701]. Neurology 2003;61:1614-1616.

2. Dobson-Stone C, Rampoldi L, Bader B, et al. Choreaacanthocytosis. In: Pagon RA, Bird TD, Dolan CR, Stephens K, eds. GeneReviews [Internet], 2010/03/20. Seattle: University of Washington, Seattle; 1993-2002.

3. Saiki S, Hirose G, Sakai K, et al. Chorea-acanthocytosis associated with Tourettism. Mov Disord 2004;19:833-836.

4. Saiki S, Sakai K, Murata KY, et al. Primary skeletal muscle involvement in chorea-acanthocytosis. Mov Disord 2007; 22:848-852.

5. Ishida C, Makifuchi T, Saiki S, Hirose G, Yamada M. A neuropathological study of autosomal-dominant choreaacanthocytosis with a mutation of VPS13A. Acta Neuropathol 2009;117:85-94.

6. Bader B, Velayos-Baeza A, Walker RH, Danek A. Dominant transmission of chorea-acanthocytosis with VPS13A mutations remains speculative. Acta Neuropathol 2009;117:9596; author reply 97-98.

7. Tomiyasu A, Nakamura M, Ichiba M, et al. Novel pathogenic mutations and copy number variations in the VPS13A gene in patients with chorea-acanthocytosis. Am J Med Genet B Neuropsychiatr Genet 2011;156B:620-631.

8. Saiki S, Sakai K, Saiki M, Hirose G. Huntington's disease: like 2 can present as chorea-acanthocytosis. Neurology 2004; 63:939-940; author reply 939-940.

\section{CORRECTION}

Pilomotor seizure: When paroxysmal gooseflesh heralds brain tumor

In the Video NeuroImage "Pilomotor seizure: When paroxysmal gooseflesh heralds brain tumor" by L. Fisch et al. (Neurology ${ }^{\circledR}$ 2012;78:1189), there is an error in the author list. The third author's name should read S. Badoud. The publisher regrets the error. 